\title{
Dependence of the Feed Environment on Protein Synthesis of Feed Insects
}

\author{
D.A. Mirzaeva ${ }^{1}$, K.S. Maksumkhodzhaeva ${ }^{1}$, N.A. Khujamshukurov ${ }^{1}$, X.O. Abdullaev ${ }^{1}$, \\ Sh.Q. Gazieva ${ }^{1}$, Sh.X. Iskhakova ${ }^{2}$ and D.Kh. Kuchkarova ${ }^{1}$ \\ ${ }^{1}$ Tashkent Chemical-Technological Institute, ${ }^{2}$ Tashkent Architectural-Civil Engineering \\ Institute, Uzbekistan \\ *Corresponding author
}

\section{A B S T R A C T}

\section{Ke y w o r ds \\ Tenebrio molitor, Yellow mealworm, Edible insects, Insects feed, Fish feed, Protein, Amino acid, Macrophytes, Lemna minor, Azolla carolina}

\section{Article Info}

Accepted: 28 March 2020 Available Online: 10 April 2020
This article analyzes the synthesis of the Tenebrio molitor protein (Coleoptera: Tenebrio nidae) belonging to a feed insect, depending on its nutrient content. Differences in protein synthesis by Tenebrio molitor larvae were shown when wheat bran and flour from the macrophytes Lemna minor and Azolla carolina were added. In particular, it was noted that TMO-2 and TMO-6 T.molitor $\mathrm{F}_{6}$ larvae are synthesized on average $31.02 \%$ protein in wheat bran, $38.13 \%$ in duckweed and $30.87 \%$ in azole. It was found that the larvae of variant $\mathrm{F}_{6}$ grown on wheat bran synthesized protein on average $4.79 \%$ less than the variant $F_{1}$ of wheat. $F_{6}$ larvae grown in duckweed synthesized $7.11 \%$ more protein than larvae grown in wheat bran and $0.15 \%$ less protein synthesis than larvae grown in azole. It was found that $F_{6}$ larvae grown in duckweed produce $7.26 \%$ more protein than larvae grown in azole. Summarizing these indicators, it was noted that in the body of larvae eating macrophytes insufficient absorption of nutrients, low moisture content in the feed led to their death, egg laying and larvae of variant $\mathrm{F}_{6}$ produced significantly less protein than variant $F_{1}$. When feeding macrophytes, it is advisable to take into account its moisture content or add flour based on them to other food sources. It was studied that egg-laying larvae grown on the basis of azole accounted for $38.14 \%$, whereas in duckweed this indicator was $58.38 \%$. It was found that in larvae grown on wheat bran, the percentage of egg-laying is $68.85 \%$. The mortality rate of larvae feeding on wheat bran was $18.22 \%$, in duckweed - $44.63 \%$, in azole - $62.27 \%$, this is due to insufficient moisture in the composition of duckweed and azolle (average humidity 3.4-4.2\%), relatively high humidity (average humidity 9.58-10.12\%) in wheat bran.

\section{Introduction}

By 2050 , there will be a problem with the provision of food to more than 9 billion people (FAO, 2009). According to FAO (2011), by 2050, compared with 2010, the demand for meat products will increase by
$58 \%$, and the demand for dairy products - by $70 \%$. Livestock farming is known to be one of the most productive sectors, with $35 \%$ of world production and $75 \%$ of agricultural production spent on developing this industry. Also, this industry consumes $8 \%$ of the world's drinking water (including food crops) 
(FAO, 2014; Foley et al., 2011). In addition, the livestock sector emits $14.5 \%$ of all anthropogenic greenhouse gases, which is about 7.1 gigatons of $\mathrm{CO}_{2}$ equivalent per year (Gerber et al., 2013). Livestock farming also requires a large amount of water (Mekonnen and Hoekstra, 2012). As a result, the cultivation of livestock products requires huge reserve resources, taking into account the production of feed. This shows that the cultivation of foods that are easy to manufacture, inexpensive and rich in all the necessary ingredients is one of the most pressing problems.

In addition, soybean flour and fishmeal are recognized separately as the main food sources to provide the fishing industry with nutritious food products in the global industry. Wheat flour and corn flour are also widely used as staple foods in fisheries. It is noted that soy flour contains $44-54 \%$ protein and 2-3\% fat (Adámková et al., 2016), while fish meal contains about $48-75 \%$ protein and 9-11\% fat (Vrabec et al., 2015).

One of the global problems is a sharp change in the natural climate, drought due to abiotic and biotic factors, a decrease in the area of land for agricultural production due to increased salinity and soil degradation, and serious problems arise in the production of agricultural products under the influence of various pests and diseases.

By breeding industrially insects with a nutritious chemical composition, it is possible to create an unlimited number of feed industries and feed additives for livestock production (van Huis et al., 2013). The fact that it is very convenient to breed insects on the basis of inexpensive secondary organic products or on the basis of biological waste shows the importance of these biological objects (Collavo et al., 2005).
Insects can also consume various processed wastes, turning them into food feeds with high nutritional value. It was shown that, reproducing a large number of insects on an industrial basis, they can be used as an alternative to the production of food feeds products with high nutritional value (Veldkamp et al., 2012). In particular, it was determined that Tenebrio molitor (larva) of various food insects retains $44-64 \%$ protein, 17-43\% fat (Finke, 2002), 40-75\% protein (Bukkens, 1997), Alphitobius diaperinus (larva) - protein 58-65\%, fat 22-29\% (Diener et al., 2009), Acheta domestica (adult) protein 58-74\%, fat 14-23\% (Oonincx and van der Poel., 2011), Gryllodes sigillatus (adult)) - protein $70 \%$, fat - 18\% (Ravzanaadii et al., 2012) Locusta migratoria (adult) protein 56-65\%, fat 13-30\% (Bednarova et al., 2013), Hermetia illucens (larvae) - protein $32-52 \%$, fat $12-42 \%$ (Rumpold and Schlüter, 2013).Thus, edible insects can be considered as an alternative source of providing the livestock, poultry, and fishing industries with a continuous nutritious feed base (Khujamshukurov., 2011). It is known that Tenebrio molitor is one of the most widely used edible insects in the world practice (Khujamshukurov et al., 2016).

Analyzing scientific sources, we can see that the data on the storage of proteins and fats, which determine their nutritional value, are different. In particular, $44-64 \%$ is retained relative to dry matter (Finke, 2002), 46.4\% (Ravzanaadii et al., 2012), 47.7\% (RamosElorduy et al., 2002), 63.3\% (Ghaly and Alcoaic., 2009), some sources report protein retention of up to $70 \%$.

In addition, the amino acids in their protein (Akhtar and Isman, 2018) and the fatty acid content of their fat are also interpreted differently (Boscou et al., 2006; Caruso et al., 2014; Jeon et al., 2016; Jokic et al., 2013; Popa et al., 2012). This may be due to the 
area of distribution of these insects, living conditions, type of feeding under controlled conditions, nutritional value of the food base.

\section{The purpose of the work}

Growing in the conditions of Uzbekistan (Tashkent Chemical-Technological Institute, Biotechnology Research Laboratory) consists in determining the stock of protein and amino acids Tenebrio molitor (Coleoptera: Tenebrio nidae).

\section{Materials and Methods}

Object of study. The sixth generation $\left(\mathrm{F}_{6}\right)$ Tenebrio molitor (Coleoptera: Tenebrio nidae) was used, collected from the southern foothills of Uzbekistan and propagated under controlled conditions. During the study, from larvae and beetles collected by nature and numbered Tenebrio molitor (128: larvae 108, 20 beetles), 2 larvae (TMO-2: $5.36 \mathrm{~cm}$, TMO6: $4.83 \mathrm{~cm})$ were selected $\left(\mathrm{F}_{1}\right.$ variant $)$, which were the largest in size compared to others, upon visual observation, a Tenebrio molitor colony was formed on their basis. Growing conditions: used dry biomass of wheat bran with a standard content (protein 14-15\%, fat $0.8-1.0 \%$ ), as well as from macrophytes Lemna minor (protein 16.1\%, fat - 2.8-3, 1\%) and Azolla carolina (protein $-27.6 \%$, fat-2.8$3.2 \%$ ). Temperature is $20-22^{\circ} \mathrm{C}$. The duration of cultivation in all samples was 28 days.

\section{Determination of proteins}

Method R. Scoups (1985) was used in protein purification. During protein separation, the dry mass of the insect was crushed and disinfected with hexane. They took $1.5 \mathrm{~g}$ of insect flour and extracted sequentially in $5 \mathrm{ml}$ of water, $5 \mathrm{ml}$ of $5 \mathrm{M}$ sodium chloride, $5 \mathrm{ml}$ of absolute methanol and $5 \mathrm{ml}$ of $0.2 \mathrm{M}$ phosphate buffer ( $\mathrm{pH}-8.0)$. Each extraction was carried out for 20 minutes. After extraction, the solutions were centrifuged for
$15 \mathrm{~min}$ at a speed of $8000 \mathrm{rpm}$. The amount of protein in the supernatant was determined by the standard Lowry method. The calculation of the statistical error, mean value, confidence intervals and standard deviations from experimental data was carried out using the STATISTICA 6.0 computer program and standard methods. The statistical significance of the results was determined using Student's t-test.

\section{Results and Discussion}

When studying the direct storage of protein of Tenebrio molitor larvae (3-4 cm long), variant $F_{1}$ collected from the Angren mountain ranges, Republic of Uzbekistan, Tashkent region, the average protein content was $43.09 \%$ (Figure 1). It was noted that the average protein content in the variants of $F_{1}$ larvae $1-3 \mathrm{~cm}$ long collected from nature is $42.74 \%$ (Fig. 2).

The average protein content in both variants was summed up and averaged $43.0 \%$. This indicator $(43.0 \%)$ was used as a control for moderate growth of Tenebrio molitor larvae and selection of culture media with different protein contents for storage. During the study, from larvae and beetles collected by nature and numbered Tenebrio molitor (128: larvae 108, 20 beetles), 2 larvae (TMO-2: $5.36 \mathrm{~cm}$, TMO-6: $4.83 \mathrm{~cm})$ were selected $\left(\mathrm{F}_{1}\right.$ variant), which were the largest in size compared to others, upon visual observation, a Tenebrio molitor colony was formed on their basis.

In this study, variants of TMO-2 and TMO-6 larvae based on variant $F_{1}$ and based on $F_{6}$ were used to study the properties of protein formation in various nutrient sources. Variants of Tenebrio molitor TMO-2 and TMO-6 larvae were used as controls for each other in the analysis of protein formation in various nutrient sources.

Although the larvae of the TMO-2 variant 
obtained on the basis of the $\mathrm{F}_{6}$ variant synthesized $30.89 \%$ of the protein in wheat bran, it was found that they synthesize $12.2 \%$ less protein than in the control variant $\left(\mathrm{F}_{1}\right)$. The TMO-2 variant grown in duckweedbased nutrient medium showed an average of $38.65 \%$ protein synthesis, $4.44 \%$ less than the $\mathrm{F}_{1}$ control, and $7.71 \%$ more protein synthesis than $F_{6}$ grown on wheat bran. Therefore, the fact that duckweed stores more protein than wheat bran from the point of view of protein storage, could serve as the basis for this. It was found that the larvae of the TMO-2 variant obtained on the basis of variant $\mathrm{F}_{6}$ synthesize an average of $31.48 \%$ of the protein when grown on the basis of azole.

It was noted that the protein synthesized is $11.61 \%$ less compared to the $\mathrm{F}_{1}$ protein variant. It was found that wheat bran produces an average of $0.59 \%$ more protein than the larvae of variant $\mathrm{F}_{6}$, and $7.17 \%$ less protein synthesis than the larvae of variant $\mathrm{F}_{6}$ grown in duckweed. The fact that less protein is synthesized in azole than in duckweed can be explained by the fact that splitting of the azole flour in the larval organism is more complicated than in duckweed flour.

The larvae of the TMO-6 Tenebrio molitor variant obtained on the basis of $\mathrm{F}_{6}$ synthesized $31.15 \%$ of the protein in wheat bran, while protein synthesis was observed to be $11.59 \%$ less compared to the control variant $\left(\mathrm{F}_{1}\right)$ (Fig. $2)$. The TMO-6 variant grown in a nutrient medium based on Lemna minor synthesized an average of $37.60 \%$ protein, $5.14 \%$ less than the $F_{1}$ control, and $6.45 \%$ more protein synthesis than the $F_{6}$ variant grown on wheat bran. Therefore, the reason for this may be the fact that the aforementioned duckweed stores more protein than wheat bran. It was observed that the larvae of the TMO-6 variant obtained on the basis of the $\mathrm{F}_{6}$ variant synthesized on average $30.26 \%$ of the protein when grown on the basis of azole and $12.48 \%$ less protein synthesis than on the $F_{1}$ control. Variant TMO-6 larvae grown on Azolla carolina flour synthesized $0.89 \%$ less protein than larvae of TMO-6 variant grown on wheat bran.

The results obtained compared the synthesis of $\mathrm{F}_{6}$ protein of the larva variant of TMO-2 and the variant TMO- 6 in food sources with an average protein synthesis of $31.02 \%$ in standard wheat bran, $38.13 \%$ in duckweed and $30.87 \%$ in azole. It was found that the larvae of variant $\mathrm{F}_{6}$ grown on wheat bran synthesized protein on average $4.79 \%$ less than variant $F_{1} . F_{6}$ larvae grown in duckweed synthesized $7.11 \%$ more protein than larvae grown in wheat bran and $0.15 \%$ less protein synthesis than larvae grown in azole. It was found that $F_{6}$ larvae grown in duckweed produce $7.26 \%$ more protein than larvae grown in azole. This means that although the source of the nutrients of the naturally harvested $\left(\mathrm{F}_{1}\right)$ larvae is unclear, they may have had high protein synthesis because they naturally fed on the most convenient and nutritious food source. The high protein synthesis of $\mathrm{F}_{6}$ larvae in wheat bran compared to duckweed can be explained by its high protein content and its easy digestion in the larval organism. However, the high protein content in azole can be explained by the fact that the larvae synthesize less protein than duckweed, which complicates the breakdown and digestion of azole in the larval organism.

However, studies have shown significant differences in the overall development and mortality of larvae feeding on duckweed and azole. In particular, the laying of eggs of larvae based on azole was $38.14 \%$, and in duckweed - 58.38\%. It was noted that the percentage of egg laying in larvae grown on wheat bran was $68.85 \%$.

The mortality rate of larvae feeding on wheat bran was only $18.22 \%$, on duckweed $44.63 \%$, and on azole $-62.27 \%$. This situation 
is explained by the fact that in duckweed and azole there is not enough moisture (average humidity $3.4-4.2 \%$ ), the content of wheat bran is relatively high (average humidity 9.58-10.12\%).

Summing up these indicators, we believe that the lack of nutrients in the body eating macrophyte larvae, the low moisture content in the feed led to their death, egg laying and larvae of variant $\mathrm{F}_{6}$ produced significantly less protein than variant $F_{1}$. Therefore, when feeding macrophytes, it is advisable to take into account its moisture content or add flour based on them to other food sources. Then the larvae can die, lay eggs and achieve maximum protein synthesis.

Figure.1 Storage of Tenebrio molitor larvae protein (TMO-2) in various nutrient media (\% of dry matter)

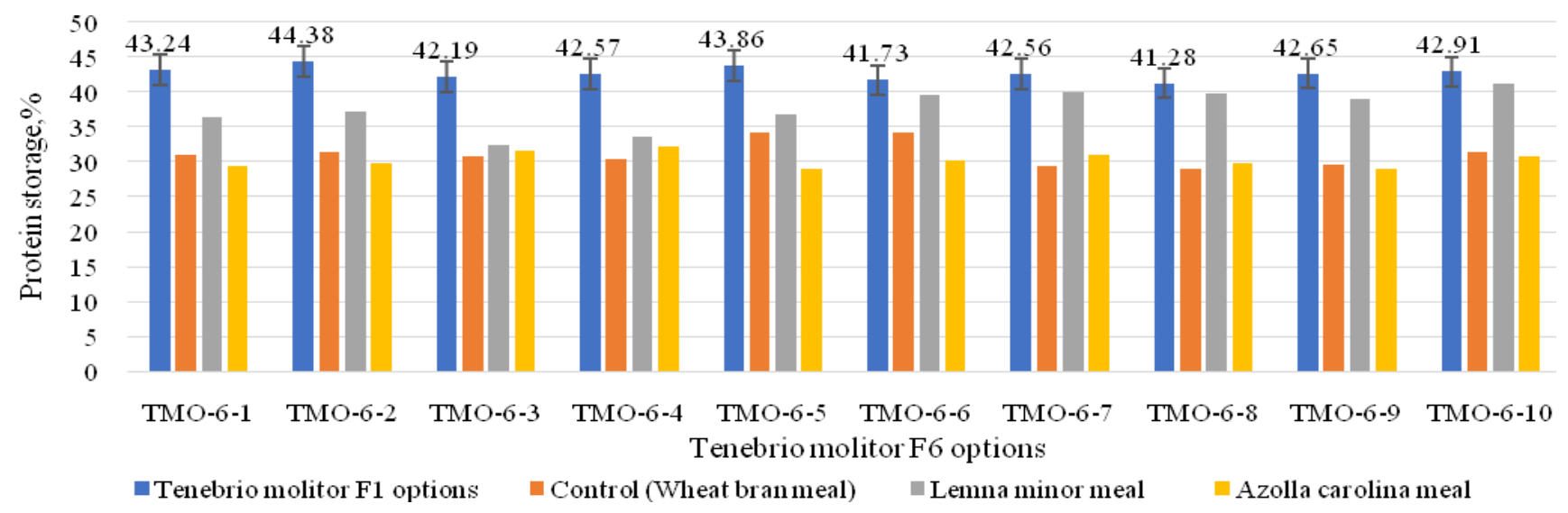

Note - option F1 is a variant collected from nature; Wheat bran: protein 14-15\%, fat 0.8-1.0\%; Duckweed: protein $16.1 \%$, fat $2.8-3.1 \%$; Azolla: protein $-27.6 \%$, fat-2.8-3.2\%

Figure.2 Storage of protein larvae of Tenebrio molitor (TMO-6) in various nutrient media (in $\%$ of dry matter)

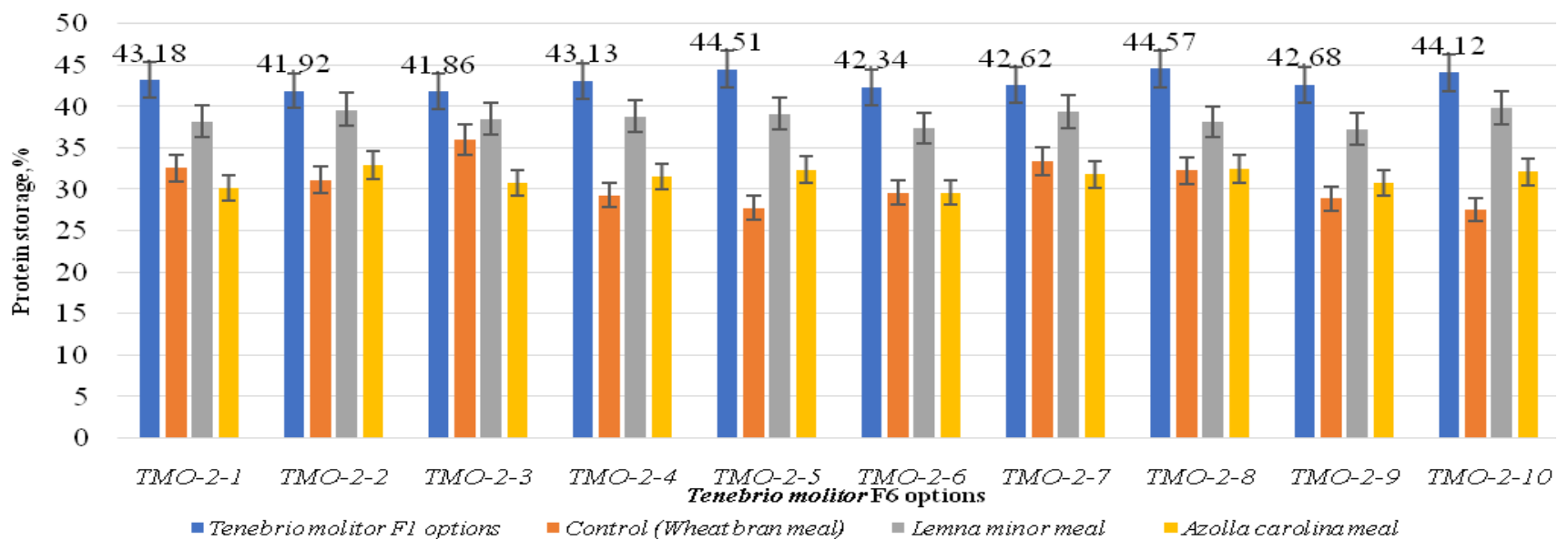

Note - option F1 is a variant collected from nature; Wheat bran: protein 14-15\%, fat -0.8-1.0\%; Duckweed: protein $16.1 \%$, fat - 2.8-3.1\%; Azolla: protein $-27.6 \%$, fat $-2.8-3.2 \%$ 
In conclusion, typically, agricultural products such as soybean meal, wheat bran, corn bran and cornmeal, which are expensive and inconvenient to grow, are used in the production of Tenebrio molitor under controlled conditions and in the production of feed products based on it. This suggests the need for alternative feed sources to organize industrial production based on edible insects. As such alternative nutrient sources, macrophytes can be considered as one of the most viable options. Favorable climatic conditions in the Republic of Uzbekistan, sunny days for at least 270 days a year, from March to mid-November, allow the cultivation of macrophytes (duckweed, azolla, euchronia, pistia, etc.) on an industrial basis.Based on just one lem Lemna spp. production capacities of $60-145 \mathrm{t} / \mathrm{ha} /$ year in Thailand-Vietnam were noted (Landolt and Kandeler, 1987), 36-51 t/ha/year in Israel (Leng et al., 1995), 7-8 t/ha/year in Russia (FAO, 2001), 7-15 t/ha/year in Uzbekistan (FAO, 2001), 22-34 t/ha/year in Germany (Mkandawire and Dudel, 2005), 30-70 t/ha/year in India (Leng at al. , 1995), 30 t/ha/year in Egypt (Landolt and Kandeler, 1987) and 57-185 t/ha/year in various regions of the USA (FAO, 2001).

Now it is clear that these numbers have increased several hundred times. In particular, based on our scientific studies, it was proved that in Uzbekistan, on the basis of the small lemna, it is possible to obtain $154 \mathrm{t} / \mathrm{ha} /$ year of wet biomass or 27.34 tons of dry mass (Khujamshukurov et al., 2012). This will allow to establish production based on edible insectsin Uzbekistan and provide its feed base based on macrophytes. From scientific sources it is known that when obtaining protein based on Tenebrio molitor, very few land areas, feed and water are required in comparison with the land plots necessary for raising chickens, pigs or cattle. In addition to its low environmental impact, this production is characterized by a very high level of productivity and the ability to organize the production process regardless of the time of year. In particular, cattle or pigs cannot feed on any plant matter, and very large plants, including macrophytes, can be used for insects.

In our study, their properties of protein synthesis during the propagation of Tenebrio molitor based on macrophytes were demonstrated. The production of feed based on edible insects will provide the fastgrowing fish industry in Uzbekistan with a source of continuous, full nutritional value. The cultivation of these species of insects using macrophytes of duckweed and azolle, which are easy to breed, will reduce their cost and increase their nutritional value.

\section{Acknowledgements}

This study was conducted as part of the scientific program of the Tashkent Institute of Chemical Technology "Development of feeding technology based on non-traditional sources."

\section{References}

Adámková A., Kouřimská L., Borkovcová M., Kulma M., Mlček J. 2016. Nutritional values of edible Coleoptera (Tenebriomolitor, Zophobasmorio and Alphitobius diaperinus) reared in the Czech Republic. Potravinarstvo Scientific Journal for Food Industry 10(1), 663671.

Akhtar Y., Isman Y.2018. Insects as an Alternative Protein Source. Proteins in Food Processing. 10. pp.263-288. https://doi.org/10.1016/B978-0-08100722-8.00011-5.

Boscou D., Blekas G., Tsimidou M. 2006. Olive oil composition. In: Chemistry, 
properties, health effects. Rome: AOCS Press, pp. 41-72.

Bukkens, S. G. F. 1997. The nutritional value of edible insects. Ecol. Food Nutr. 36 (2-4), 287-319.

Caruso D., Devis E., Subamia IW., Talamond P., Baras E. 2014. Technical handbook of domestication and production of DipteraBSF. IRD ED., IPB Press.

Collavo A., Glew R.H., Huang YS., Chuang LT., Bosse R., Paoletti M.G. 2005. House Cricket Small-scale Farming// Ecological Implications of Minilivestock. Pp.515-540.;

Diener S., Zurbrügg C., Tockner K. 2009. Conversion of organic material by black soldier fly larvae: establishing optimal feeding rates. Waste Management Research. 27(6): 603610.

FAO. 2001. Duckweed: A tiny aquatic plant with enormous potential for agriculture and environment. Food and Agriculturally Organization, Geneva. Pp.108.

FAO. 2009. FAO's Director-general on how to feed the world in 2050. Popul. Dev. Rev. 35, 837-839. doi:10.1111/j.17284457.2009.00312.x.

FAO/WUR. 2014: Insects to feed the world: summary report. In: Vantomme, P., Münke, C., van Huis, A., van Itterbeeck, J., Hakman, A. (Eds.): Insects to Feed the World. Ede, Netherlands.

Finke M. D. 2002. Complete nutrient composition of commercially raised invertebrates used as food for insectivores. Zoo Biology 21(3), 269285.

Foley Jonathan A., RamankuttyNavin, Brauman Kate A., Cassidy Emily S., Gerber James S., Johnston Matt, Nathaniel D. Mueller, Christine O'Connell, Deepak K. Ray, Paul C. West, Christian Balzer, Elena M.
Bennett, Stephen R. Carpenter, Jason Hill, Chad Monfreda, Stephen Polasky, Johan Rockstro"m, John Sheehan, Stefan Siebert, David Tilman and David P.M. Zaks. 2011. Solutions for a cultivated planet/Nature. Vol.478. Pp.-337-342. doi:10.1038/nature10452).

Gerber P.J., Steinfeld H., Henderson B., Mottet A., Opio C., Dijkman J., Falcucci A., Tempio G. 2013. Tackling climate change through livestock - A global assessment of emissions and mitigation opportunities. Food and Agriculture Organization of the United Nations (FAO), Rome. Pp.-139.

Ghaly A.E., Alkoaik F.N. 2009. The yellow mealworm as a novel source of protein. Am. J. Agric. Biol. Sci. 4(4);319-331.

Jeon YH., Son YJ., Kim SH., Yun EY., Kang HJ., Hwang IK. 2016. Physicochemical properties and oxidative stabilities of mealworm (Tenebrio molitor) oils under different roasting conditions. Food Sci. Biotechnol. 25: 105-110.

Jokic S., Sudar R., Svilovic S., Vidovic S., Bilic M., Velic D., et al., 2013. Fatty acid composition of oil obtained from soybeans by extraction with supercritical carbon dioxide. Czech J. Food. Sci. 31: 116-125.

Khujamshukurov N.A. 2011. Alternative protein products. J. XXI-technology. №4 (5):14-15

Khujamshukurov N.A., Nurmuxamedova V.Z. 2016. Production feed: modern trend and development aspect. Scientific overview. J. Zooveterinary. №8 (105):34-37.

Landolt E., Kandeler E. 1987. The Family Lemnaceae: A monographic study (vol.2) Phytochemistry, Physiology, Application, Bibliography, Verof- 
fentlichungen des Geobotanischen Institutes der ETH 1, Stiftung Rubel, Zurich. Pp.638.

Leng RA., Stambolie JH., Bell R. 1995. Duckweed- a potential high-protein feed resource for domestic animals and fish Livestock Research for Rural Development 7.

Mekonnen M.M., Hoekstra A.Y. 2012. A Global Assessment of the Water Footprint of Farm Animal Products// Ecosystems, 15:401-415. DOI: 10.1007/s10021-011-9517-8).

Oonincx D.G., Van der Poel A.F. 2011. Effects of diet on the chemical composition of migratory locusts (Locustamigratoria). Zoo Biology.30(1):9-16.

Popa V-M., Gruia A., Raba D-N., Dumbrava D., Moldovan C., Bordean D., et al., 2012. Fatty acids composition and oil characteristics of linseed from Romania. J. Agroalm. Process Technol. 18: 136-140.

Ramos-Elorduy J., Gonzalez E.A., Hernandez A.R. and Pino J.M. 2002. Use of Tenebrio molitor (Coleoptera: Tenebrionidae) to recycle organic wastes and as feed for broiler chickens. J. Econ. Entomol. 95(1): 214-220.

Ravzanaadii N., Kim S.H., Choi W.H., Hong S.J., Kim N.J. 2012. Nutritional value of mealworm, Tenebrio molitor as food source. International Journal of Industrial Entomology. 25(1):93-98.

Rumpold BA, Schluter OK. 2013. Nutritional composition and safety aspects of edible insects. Mol. Nutr. Food Res. 57(5): 802-823.

Scoups R. Methods cleaning proteins. Moscow. 1985. Pp.341-342c.

Steven A., Cohen Daviel J. Amino acid analysis utilizing phenylisothiocyanate derivatives // Jour. Analytical Biochemistry. 1988. V.17. № 1. P.116.

van Huis A., Van Itterbeeck J., Klunder H., Mertens E., Halloran A., Muir G., Vantomme P. 2013. Edible insects Future prospects for food and feed security. FAO Forestry, Paper 171.

Veldkamp T., van Duinkerken G., van Huis A., Lakemond C.M.M., Ottevanger E., Bosch G., van Boekel M.A.J.S. 2012. Insects as a sustainable feed ingredient in pig and poultry diets - a feasibility study. Rapport 638 -Wageningen Livestock Research.

Vrabec V., Kulma M., Cocan D. 2015. Insects as an alternative protein source for animal feeding: a short review about chemical composition. Bulletin of the University of Agricultural Sciences and Veterinary Medicine Cluj-Napoca Animal Science and Biotechnologies. 72(2):116-126.

\section{How to cite this article:}

Mirzaeva, D.A., K.S. Maksumkhodzhaeva, N.A. Khujamshukurov, X.O. Abdullaev, Sh.Q. Gazieva, Sh.X. Iskhakova and Kuchkarova, D.Kh. 2020. Dependence of the Feed Environment on Protein Synthesis of Feed Insects. Int.J.Curr.Microbiol.App.Sci. 9(04): 3225-3232. doi: https://doi.org/10.20546/ijcmas.2020.904.375 